\title{
ANALISIS MEKANISME IZIN PEMASANGAN REKLAME DIKANTOR PELAYANAN PERIZINAN TERPADU KOTA MEULABOH
}

\author{
Alimas Jonsa \\ Khairul Azwar \\ Program Studi Ilmu Administrasi, Universitas Teuku Umar \\ Email: alimasjonsa@gmail.com
}

\begin{abstract}
The purpose of this research is to know the licensing mechanism to install billboards, to know what constraints faced by the Office of Integrated Licensing Service (KPPT) in licensing to install billboard and to know the strategy of supervision on the implementation of advertisement by KPPT in West Aceh regency. The method used in this research is descriptive research method with qualitative approach. Selection of informants in this study carried out by purposive sampling method is a technique of sampling data sources with certain considerations. The informants in this study were Head of Program and Information (KPPT), Petitioner of License (Public), Regional Financial Management and Wealth Official (Additional Informant) and Satpol PP (Additional Informant) with total of informant ie 7 people who made sample in this research. Based on the results of research indicate that the service procedure at KPPT when viewed from the aspect of simplicity, clarity and certainty of requirements as well as details of retribution fee (Tax), legal certainty, responsibility, completeness of facilities and infrastructure and ease of access. Obstacles faced by the KPPT, among others, due to the large number of people who take care of the billboard permit and the society did not complete the requirements requested so that the process of issuing the permit to establish a billboard become obstructed. Strategy of supervision on the implementation of advertisements is to follow up unlicensed billboards.
\end{abstract}

Keywords: Analicys, Installation Permit Mechanism Billboards, KPPT.

\section{PENDAHULUAN}

Implementasi kebijakan dalam otonomi daerah, pemerintah telah menetapkan beberapa kebijakan untuk meningkatkan pelayanan kepada masyarakat didaerah, diantaranya adalah kebijakan meningkatkan pelayanan masyarakat di bidang perizinan. Seperti dinyatakan dalam Peraturan Pemerintah Nomor 41 Tahun 2007 tentang Organisasi Perangkat Daerah, pada pasal 47 bahwa untuk meningkatkan dan keterpaduan palayanan masyarakat dibidang perizinan yang bersifat lintas sektor, Gubernur, Bupati, atapun Walikota dapat membentuk unit pelayanan terpadu (dengan sebutan Badan atau Kantor), yang merupakan gabungan unsur-unsur perangkat daerah yang menyelenggarakan fungsi pelayanan perizinan.

Sebagai implementasi dari peraturan pemerintah tersebut kemudian ditetapkan Peraturan Mendagri Nomor 20 Tahun 2008 tentang Pedoman Organisasi dan Tata Kerja Unit Pelayanan Perizinan Terpadu di Daerah, dimana pada pasal 4 disebutkan bahwa Badan atau Kantor Pelayanan Perizinan Terpadu mempunyai tugas melaksanakan koordinasi dan menyelenggarakan pelayanan administrasi dibidang perizinan secara terpadu dengan prinsip koordinasi, integrasi, sinkronisasi, simplikasi, keamanan dan kepastian. Fungsi Badan atau Kantor Pelayanan Perizinan Terpadu adalah penyelenggaraan pelayanan administrasi perizinan.

Perizinan (verguning) merupakan suatu persetujuan dari penguasa berdasarkan UndangUndang atau Peraturan Pemerintah dalam keadaan tertentu atau perbuatan hukum administrasi 
Negara bersegi satu yang mengaplikasikan peraturan dalam hal konkrit berdasarkan persyaratan dan prosedur sebagaimana ditetapkan oleh ketentuan peraturan Perundang-Undangan, sedangkan mekanisme perizinan merupakan sebuah upaya yang dilakukan untuk memberikan penjelasan seputar sistem mekanisme didalam perizinan (Adrian Sutedi, 2010, hal. 168).

Pemberian pelayanan prima oleh aparatur pemerintahan kepada masyarakat merupakan suatu keharusan dan tidak bisa ditawar lagi, karena hal ini merupakan esensi bagian dari tugas pokok dan fungsi pemerintahan dalam menjalankan tugas-tugas pemerintahan dalam pemberian pelayanan prima kepada masyarakat harus tetap dilaksanakan (Napitupulu, 2006 hal. 130).

Penyediaan pelayanan perizinan, petugas birokrasi sering kali memberikan prosedur yang sangat rumit dan cendrung betele-tele, jika mekanisme yang rumit terus berjalan, otomatis membuat masyarakat menjadi malas dan apatis dalam mengurus perizinan.Maka pemerintah perlu mencari solusi untuk mengatasi masalah-maslah tersebut.

Presiden Susilo Bambang Yudhoyono pernah menjamin bahwa pelayanan pengurusan izin-izin usaha tidak akan sulit. Apabila ada oknum yang mempersulit dalam pengurusan izin-izin usaha tersebut, maka masyarakat boleh mengirim surat keluhan ke PO BOX 10000 (Goenawan, 2008 hal. 4).

Berdasarkan hasil studi International Finance Coorporation (IFC) Bank Dunia pada tahun 2006, peringkat Indonesia menurun dari 131 pada tahun 2005 menjadi 135 pada tahun 2006, jika dibandingkan dengan negara lain di ASIA, untuk memulai pengurusan perizinan suatu usaha di berbagai instansi pusat dan daerah membutuhkan 12 prosedur yang harus dilalui dengan waktu dibutuhkan selama 97 hari, biaya yang diperlukan sebesar US\$1.110. Perbandingan di negara lain seperti Malaysia 9 prosedur dan waktu dibutuhkan 30 hari serta biaya yang diperlukan sebesar US\$ 997. Vietnam dengan 11 prosedur, waktu yang dibutuhkan 50 hari dan biaya yang diperlukan US\$276.(http://www.perizinan. info/fom_index.php .com/29-12-2009/20.33 WIB).

Perizinan merupakan salah satu aspek penting dalam pelayanan publik. Kendatipun tidak dibutuhkan setiap hari tetapi sangat berperan penting bagi kehidupan kita, namun banyak yang tidak dapat kita lakukan karena izin adalah bukti penting secara hukum (Khayatudin, 2012:h.103). Salah satu yang membutuhkan perizinan yaitu mendirikannya papan reklame. DalamPeraturan Bupati Aceh Barat Nomor 81 Tahun 2014 Tentang Tata Cara Pelaksanaan Pajak Reklame yaitu benda, alat, perbuatan atau media yang membentuk dan corak ragamnya dirancang untuk tujuan komersial, memperkenalkan, menganjurkan, mempomosikan atau untuk menarik perhatian umum terhadap barang, jasa, orang atau badan yang dapat dilihat, didengar, dirasakan dan atau diminati oleh umum.

Jenis reklame dibedakan atas dua jenis yaitu reklame tetap terbatas dan reklame insidentil. Reklame tetap terbatas merupakan reklame yang mendapatkan izin tertulis untuk menyelenggarakan reklame yang berlaku selama satu tahun, sedangkan reklame insidentil yaitu reklame yang mendapatkan izin tertulis untuk menyelenggarakan reklame yang berlaku kurang dari satu tahun.

Reklame/iklan dan promosi merupakan bagian yang tidak terpisahkan dari sistem dan sosial masyarakat modern. Dewasa ini reklame/iklan sudah berkembang menjadi suatu sistem komunikasi yang sangat penting tidak saja bagi produsen produk dan jasa tetapi juga bagi konsumen. Kemampuan reklame/iklan dan metode promosi lainnya dalam menyampaikan pesan kepada konsumen menjadikan kedua bidang tersebut memegang peran sangat penting bagi keberhasilan perusahaan dalam memasarkan produk dan jasanya (Masli Ali, 2005:hal.7).

Berbagai bentuk usaha, mulai dari usaha eceran, hingga perusahaan multinasional mengandalkan reklame/iklan dan promosi untuk menjunjung pemasaran produk dan jasa mereka kepada masyarakat. Pada sistem ekonomi yang berlandaskan pada pasar, konsumen semakin mengandalkan reklame/iklan dan bentuk promosi lainnya untuk mendapatkan informasi yang akan mereka gunakan untuk membuat suatu keputusan, apakah akan membeli suatu produk dan jasa atau tidak. Semakin meningkat pengeluaran (belanja) reklame/iklan yang dilakukan 
perusahaan, maka semakin meningkat pula kuantitas pemasaran dari produk dan jasa tersebut. Hal ini membuktikan bahwa iklan/reklame dan promosi lainnya dalam memasarkan suatu produk cukup signifikan dalam mendukung pemasaran produk tersebut kepada masyarakat (Rusmanto, 2010:hal.7).

Reklame memiliki potensi yang cukup besar di kota Meulaboh sebagai penyumbang kas pemerintah daerah maupun sebagai dampak negatf yang ditimbulkan. Reklame digunakan karena memiliki potensi positif untuk menyampaikan dan menginformasikan produk-produk bagi pengguna jalan. Dengan banyak reklame di kota Meulaboh maka berbanding lurus dengan ancaman yang timbul di kota Meulaboh maupun kerusakan keindahan kota Meulaboh dengan banyak reklame. Banyaknya tiang-tiang raksasa yang dapat merugikan material maupun nyawa seseorang.Oleh karena itu diperlukan mekanisme dalam memberi perizinan untuk mendirikan reklame.

Pengurusan izin telah terdesentralisasi kepada Pemerintah Daerah, sehingga hambatan dan persoalan akan dirasakan oleh masing-masing Pemerintah Daerah. Lamanya pengurusan izin, rumitnya prosedur perizinan, mahalnya biaya yang harus dipikul oleh pemohon izin, dan berbagai persoalan lain, termasuk setelah surat izin terbit yang sering dirasakan oleh masyarakat. Ada berbagai macam bentuk izin yakni pengurusan mendirikan tempat hiburan, izin mendirikan Rumah Makan, izin produksi makanan dan minuman, izin membuka warnet dan wartel serta izin pemasangan iklan atau Reklame atau spanduk. (Sri, Pudyatmoko. 2009:hal. 58).

Seiring dengan kemajuan pembangunan dan perkembangan dunia bisnis di Kabupaten Aceh Barat kondisi reklame, baliho, maupun spanduk-spanduk iklan khususnya pemasangan spanduk atau baliho untuk Pemilihan Pemimpin Daerah sedang ramai didirikan di jalan raya, karena secara tidak langsung reklame adalah media penting dan efektif untuk memperkenalkan, menawarkan dan mempromosikan hasil suatu produk atau barangnya kepada masyarakat luas, tetapi dewasa ini keberadaan papan-papan reklame, baliho, maupun spanduk-spanduk iklan di Kota Meulaboh semakin banyak dan menumpuk keberadaannya tanpa memperhatikan tata letak sehingga sangat mengganggu kenyamanan masyarakat atau pengguna jalan. Reklame di Kota Meulaboh yang ada saat ini sudah seperti tanaman yang tiangnya menancap disetiap tanah dan bangunan ditepian jalan.Keberadaannya tak teratur seolah semua orang bebas memasang reklame sesuka hati.Berkembangnya pembangunan khusunya papan reklame, baliho, spanduk-spanduk iklan tentu saja harus ada kendali dari pemerintah daerah salah satunya adalah dengan menerbitkan izin.Keluhan pengguna jalan dalam keindahan jalan sangat dirasakan sebagian masyarakat. Dari berbagai analisa yang muncul, dapat diketahui bahwa pengelolaan reklame di kota Meulaboh masih perlu dikaji kembali. Oleh karena itu, di dalam penelitian ini.

\section{METODE PENELITIAN}

a. Metode Penelitian

Metode penelitian merupakan proses, prinsip dan prosedur yang gunakan untuk mendekati masalah dan mencari jawaban. Penelitian ini menggunakan pendekatan kualitatif dengan jenis deskriptif. Dalam penelitian ini mendeskripsikan data dalam bentuk laporan dan uraian mengenai mekanisme izin pemasangan reklame di Kantor Pelayanan Perizinan Terpadu (KPPT) Kecamatan Johan Pahlawan Kabupaten Aceh Barat.

Denzin dan Lincoln (2009 hal. 38), menyatakan menyatakan bahwa penelitian kualitatif merupakan penelitian yang menggunakan latar belakang ilmiah, dengan maksud menafsirkan fenomena yang terjadi dan dilakukan dengan jalan melibatkan berbagai metode yang ada. Hasil akhir dari penelitian kualitatif diharapkan mampu menghasilkan informasi-informasi yang bermakna atau bahkan menghasilkan ilmu baru sebagai rekomendasi untuk meningkatkan taraf hidup manusia. 


\section{b. Fokus Penelitian}

Penelitian ini berfokus bagaimana mekanisme izin pemasangan reklame di Kantor Pelayanan Perizinan Terpadu (KPPT) Kecamatan Johan Pahlawan Kabupaten Aceh Barat, apakah sudah sesuai dengan prosedur atau tidak dan apasaja kendala yang dihadapi oleh pihak penyelenggara dalam memberikan izin pemasangan reklame.

\section{c. Lokasi Penelitian}

Lokasi penelitian menunjukkan pada tempat lokasi atau lokasi penelitian yang di cirikan oleh adanya unsur yaitu pelaku, tempat, dan kegiatan yang dapat di observasi (Nasution, 2003: hal. 43).

Adapun lokasi dalam penelitian ini adalah di Kantor Pelayanan PerizinanTerpadu (KPPT) Kecamatan Johan Pahlawan Kabupaten Aceh Barat di pilihnya lokasi Tempat Kantor Pelayanan Perizinan Terpadu (KPPT) karena kantor tersebutlah yang mengeluarkan izin mendirikan reklame khususnya tentang mekanisme perizinan reklame di Kabupaten Aceh Barat.

\section{d. Sumber Data dan Teknik Pengumpulan Data}

\section{$>$ Sumber data}

Menurut Sudrajat, (2005:h.115) sumber data adalahsubjekdaripenelitian yang dimaksud. Adapun sumber data yang diambil dalam penelitian ini adalah

Data Primer yaitu data yang diperolehlangsungdariobyek yang akanditeliti (responden). Pengumpulan data primer denganmenggunakan instrument penelitian, yaituwawancara atauinterview guied (Bagong Suyanto dan Satinah, 2008:h.55). Data primer dalam penelitian ini dikumpulkan melalui penelitian langsung di lapangan yang bersumber pada penelitian wawancara dan observasi. Data primer dalam penelitian ini dikumpulkan melalui wawancara dengan pengurusan KPPT (Kantor PelayananPerizinanTerpadu). Sedangkan observasi dilakukan untuk mengetahui kondisi lokasi penelitian.

Data Sekunder adalah data yang diperoleh oleh orang yang melakukan penelitian dari sumber-sumber yang telah ada. Data sekunder merupakan data yang didapat dari studi kepustakaan, dokumen, koran, internet yang berkaitan dengan kajian penelitian yang diteliti oleh penulis (Bungin. 2008:h.122).

\section{$>$ Teknik Pengumpulan Data}

Untuk memperoleh data yang diperlukan dalam penelitian ini, penulis menggunakan beberapa tehnik pengumpulan data yaitu melalui, wawancara mendalam (in depth interview), dokumentasi dan observasi (pengamanan). Teknik pengumpulan data yang digunakan dalam penelitian ini yaitu:

Observasi adalah melakukan pengamatan dan pencatatan suatu objek, secara sistematik yang diselidiki. Observasi dapat dilakukan sesuai atau berulangkali (Sukandarrumidi, 2002:h.35). Dalam observasi melibatkan dua komponen, yaitu pelaku observasi (disebut sebagai observer), dan objek yang di observasi (disebut sebagai observee).

Wawancara Menurut Soehartono, (2008:h.67) wawancara adalah pengumpulan data dengan mengajukan pertanyaan secara langsung oleh pewancara (pengumpulan data) kepada responden, dan jawaban-jawaban responden dicatat atau direkam dengan alat perekam (tape recorder). Teknik wawancara dapat digunakan pada responden yang buta huruf atau tidak terbiasa membaca dan menulis, termasuk anak-anak. Wawancara dapat dilakukan dengan telepon.

Dokumentasi Menurut Soehartono, (2008:h.70) studi dokumentasi merupakan teknik pengumpulan data yang tidak langsung ditujukan kepada subjek penelitian. Dokumen yang diteliti dapat berupa berbagai macam, tidak hanya dokumen resmi. Dokumen dapat dibedakan menjadi 
dokumen primer, jika dokumen ini ditulis oleh orang yang langsung mengalami suatu peristiwa, dan dokumen sekunder, jika peristiwa dilaporkan kepada orang lain yang selanjutnya ditulis oleh orang lain.

Dokumen dapat berupa buku harian, surat pribadi, laporan, notulen rapat, catatan kasus (case record) dalam pekerjaan sosial, dan dokumen lainnya. Akan tetapi, perlu di ingat bahwa dokumen-dokumen ini di tulis tidak untuk tujuan penelitian sehingga penggunaannya memerlukan kecermatan penelitian. Adapun dokumentasi dalam penelitian ini berupa dokumen tertulis seperti Undang-undang, perkapdan lain-lain dan dokumen foto-foto kegiatan penelitian.

\section{e. Informan Penelitian}

Informan merupakan sebagian dari seluruh individu yang menjadi objek penelitian, yang bertujuan untuk memperoleh keterangan mengenai objek penelitian dengan cara mengamati hanya sebagian dari populasi, suatu reduksi terhadap jumlah objek penelitian (Mardalis, 2003 hal. $56)$.

Dalam melakukan teknik pengambilan informan penulis menggunakan metode purposive sampling.Purposive sampling merupakan teknik pengambilan sampel sumber data dengan pertimbangan tertentu. Pertimbangan tertentu ini, misalnya orang tersebut yang dianggap paling tahu tentang apa yang kita harapkan, atau mungkin dia sebagai penguasa sehingga akan memudahkan peneliti menjelajahi obyek atau situasi sosial yang diteliti (Sugiyono, 2013, hal. 218-219).

Maksudnya penelitian menentukan sendiri informan yang akan diambil karena ada pertimbangan tertentu. Jadi informan yang diambil tidak secara acak, tetapi ditentukan sendiri oleh peneliti yaitu mereka yang dianggap mengerti dan memahami masalah yang sedang penulis teliti. Adapun yang menjadi informan dalam penelitian ini adalah sebagai berikut.

Tabel 3.1 Informan Penelitian

\begin{tabular}{clc}
\hline No & \multicolumn{1}{c}{ Informan (Sampel) } & llah Informan \\
\hline 1. & Kasie Program dan Informasi (KPPT) & 1 \\
2. & Pemohon Izin (Masyarakat) & 4 \\
3. & Dinas Pengelolaan Keuangan dan Kekayaan & 1 \\
4. & Daerah (Informan Tambahan) & 1 \\
\hline & Satpol PP (Informan Tambahan) & $\mathbf{7}$ \\
\hline
\end{tabular}

Sumber: Data Primer yang diolah 2016

Berdasarkan tabel 3.1 diatas bahwa informan terdiri Penelitian ini terdiri dari Kasi Program dan informasi(KPPT), Pemohon Izin (Masyarakat), Kabid Pendapatan Daerah (DPKKD) dalam Pemungutan Pajak Reklamedan Satpol PP dalam penertiban reklame yang telah habis masa waktu perizinannya atau yang tidak memiliki izin (reklame liar) dengan total keseluruhan informan yaitu 7 orang yang di jadikan sampel dalam penelitian ini.

\section{PEMBAHASAN}

a. Sejarah Singkat Berdirinya Kantor Pelayanan Perizinan Terpadu (KPPT).

KPPT Kabupaten Aceh Barat dibentuk pertama kali dengan Peraturan Bupati Aceh Barat Nomor 12 Tahun 2007 tentang Susunan Organisasi dan Tata Kerja Kantor Perizinan Terpadu Satu Pintu, dan mulai operasionalnya pada tanggal 01 Nopember 2007, kemudian Istilah KPTSP diubah menjadi KPPT melalui Qanun Kabupaten Aceh Barat Nomor 4 Tahun 2008 tentang Susunan Organisasi dan Tata Kerja Lembaga Teknis Daerah Kabupaten Aceh Barat sebagaimana telah diubah beberapa kali terakhir dengan Qanun Kabupaten Aceh Barat No. 4 Tahun 2013 
tentang Perubahan Atas Qanun Kabupaten. Aceh Barat No. 11 Tahun 2012 tentang Susunan Organisasi dan Tata Kerja Lembaga Teknis Daerah Kabupaten Aceh Barat.

\section{b. Deskripsi Profil Informan Penelitian}

Berdasarkan hasil observasi dilapangan maka total keseluruhan informan yaitu 10 orang, dimana subyek dalam penelitian ini adalah Kasie Program dan informasi KPPT, Kabid Pendapatan Daerah (DPKKD), Satpol PP dan Pemohon Izin (Masyarakat) Kabupaten Aceh Barat. Peneliti melakukan wawancara dengan subyek penelitian yang telah dijadikan sampel yang dianggap mewakili populasi. Popolasi yang di jadikan sampel dari penelitian ini yaitu satu orang Kasie Program dan informasi KPPT, satu orang Kabid Pendapatan Daerah, satu orang Satpol PP, tujuh orang Pemohon Izin (Masyarakat).

\section{c. Hasil Penelitian}

Data yang akan penulis sajikan mengenai izin pemasangan reklame dan pelayanan perizinan terpadu (KPPT) adalah data primer dan data sekunder. Kemudian akan penulis analisis dan interpretasikan secara deskriptif kualitatif. Adapun data yang akan disajikan dalam penulisan ini yaitu penyajian data hasil wawancara dari informan kunci (key informan) yaitu Kasi Program dan informasi KPPT, Kabid Pendapatan Daerah (DPKKD), masyarakat yang mengurus izin mendirikan reklame sebanyak empat orang, serta informan tambahan yaitu satpol pp yang bertugas mengontrol atau mengendalikan apabila ada masyarakat yang tidak mempunyai izin dalam mendirikan papan reklame. Dan berikut hasil wawancara yang penulis sajikan dalam bentuk uraian-uraian dan penjelasan-penjelasan sesuai dengan keterangan yang diberikan oleh informan yang bersangkutan.

\section{d. Hasil Wawancara dengan Kasie Program dan informasi KPPT Kesederhanaan}

Untuk mengetahui apakah prosedur pelayanan tidak berbelit-belit dan dapat dilaksanakan secara mudah, cepat, tepat, dan lancar maka pertama sekali penulis melakukan wawancara dengan Kasi Program dan informasi KPPT tentang mekanisme izin pemasangan reklame di kantor pelayanan perizinan terpadu Kabupaten Aceh Barat.

Hasil penelitian mengenai mekanisme izin pemasangan reklam di Kabupaten Aceh Barat. Berikut hasil wawancaranya dengan Kasi Program dan informasi KPPT Kabupaten Aceh Barat Bapak Teuku Armia, SH beserta dengan pertanyaannya:

Bagaimanakah prosedur atau mekanisem pengurusan izin pemasangan reklame yang selama ini diberikan oleh pihak Kantor Pelayanan Perizinan Terpadu (KPPT) kepada masyarakat (Pemohon Izin)?

"Prosedur dalam pengurusan izin pemasangan reklame sama halnya dengan permohonan izin mendirikan usaha lainnya. Pemohon harus mengajukan permohonan kepada Kepala

Kantor Pelayanan Perizinan Terpadu (KPPT). Formulir permohonan itu berupa formulir permohonan mendiririkan reklame yang sudah disiapkan oleh petugas kami. Lalu apabila semua persyaratan telah dilengkapi oleh si pemohon seperti pembayaran pajak reklame dari kantor DPKKD, maka penerbitan izin dapat selesai dalam waktu 5 hari."

Apakah dengan adanya prosedur tersebut, pemberian Izin Pendirian reklame menjadi lebih mudah, cepat, dan lancar?

"Ya, tentu saja. Sebelumnya pengurusan izin Reklame ataupun izin lainnya di bawah naungan Dinas Kantor Perizinan Terpadu Satu Pintu, Namun sejak keluarnya Qanun Kabupaten Aceh Barat Nomor 4 Tahun 2008 tentang Susunan Organisasi dan Tata Kerja 
Lembaga Teknis Daerah Kabupaten Aceh Barat Istilah KPTSP diubah menjadi KPPT. Kemudian sebagaimana telah diubah beberapa kali terakhir dengan Qanun Kabupaten. Aceh Barat No. 4 Tahun 2013 tentang Perubahan Atas Qanun Kabupaten. Aceh Barat No. 11 Tahun 2012 tentang Susunan Organisasi dan Tata Kerja Lembaga Teknis Daerah Kabupaten Aceh Barat untuk mempermudah proses perizinan melalui satu pintu dengan menyederhanakan prosedur perizinan tersebut sehingga proses perizinan tidak berbelitbelit.

\section{Kejelasan dan Kepastian}

Untuk mengetahui kejelasan dan kepastian pelayanan Izin mendirikan Reklame yang menyangkut persyaratan pengurusan izin, rincian biaya/tarif pelayanan serta tata cara pelayanan, maka peneliti bertanya kepada Bapak Teuku Armia, SH dengan pertanyaan:

- Apa-apa saja persyaratan teknis dan administrasi dalam pengurusan Izin Pemasangan Reklame?

"Pertama-tama mengisi formulir permohonan izin reklame yang telah di sediakan oleh petugas kami dengan persyaratan antara lain fotocopy KTP pemohon izin, fotocopy bukti pajak reklame, izin pemilik tanah dalam mendirikan reklame, foto merk reklame berwarna dengan ukuran foto $5 \mathrm{R}$ dan map folio sebanyak 1 buah.

- Berapa biaya yang dikenakan untuk mengurus izin mendirikan reklame?

"Untuk biaya mengurus izin mendirikan reklame kami tidak memungutnya kami hanya mengeluarkan surat izin apabila persyaratan-persyaratan sudah dilengkapi oleh si pembohon, untuk masalah biaya mendirikan reklame biasanya hanya di kenakan biaya pajak itupun tergantung besar kecilnya ataupun banyaknya reklame yang akan di pasang apabila tanda bukti pembayaran pajak di kator DPKKD sudah ada dan persyaratan yang lain sudah lengkap maka kami akan mengeluarkan surat izinya dalam waktu kurang lebih 5 hari kerja.

\section{Kepastian Waktu}

Untuk mengetahui apakah pemrosesan permohonan izin dapat diselesaikan dalam kurun waktu yang telah ditentukan, peneliti melakukan wawancara kepada Bapak Teuku Armia, SH dengan pertanyaan:

- Berapa hari lamanya pengurusan Izin Pemasangan Reklame?

"Apabila si pemohon telah melengkapi segala persyaratan dalam pengurusan pendirian izin reklame tersebut dan fotocopy bukti pajak reklame maka pengurusan penerbitan izin pendirian reklame dapat selesai dalam waktu 5 hari. Namun karena banyaknya masyarakat yang mengurus izin mengakibatkan pekerjaan kita semakin bertambah sehingga bisa saja memakan waktu lebih dari lima hari.

- Apakah kepastian waktu penyelesaian pelayanan telah diinformasikan dengan jelas?

"Ya tentu saja pada saat si pemohon ingin mengurus permohonan izin mendirikan reklame tersebut kita telah sampaikan bahwa pengurusan izin mendirikan reklame dapat selesai dalam waktu 5 hari jika semua persyaratan telah dilengkapi dan tidak ada kendalaapapun. Namun jika memang tidak bisa selesai dalam waktu yang telah ditentukan maka kita beritahukan juga kepada si pemohon supaya tidak terjadi kesalahpahaman." 


\section{$>$ Kepastian Hukum}

Untuk mengetahui apakah persyaratan, pemrosesan, dalam pembiayaan telah sesuai dengan ketentuan yang telah ditetapkan dan apakah dokumen perizinan tersebut telah memberikan jaminan legalitas usaha dan rasa aman bagi pemegangnya, peneliti melakukan wawancara kepada Bapak Teuku Armia, SH dengan pertanyaan:

Apakah persyaratan maupun pemrosesan dalam pengurusan izin mendirikan reklame telah sesuai dengan ketentuan perundang-undangan?

"Ya tentu saja bahwa segala persyaratan maupun pemrosesan dalam sesuai dengan Peraturan Bupati Aceh Barat Nomor 81 Tahun 2014 tentang tata cara pelaksanaan pajak reklame".

Apakah pemberian Izin Pemasangan Reklame disertai dengan dokumen perizinan/tanda bukti yang sah secara hukum dan apakah dokumen perizinan/tanda bukti tersebut telah memberikan jaminan legalitas bagi si pemohon Izin Pemasangan Reklame?

"Ya, karena dokumen perizinan/tanda bukti yang sah secara hukum sangat penting sekali karena dengan adanya dokumen perizinan/tanda bukti tersebut tentu saja telah memberikan jaminan legalitas terhadap si pemohon dan dengan tanda bukti resmi tersbut juga sebagai bukti dalam pengurusan reklame yang dapat digunakan oleh si pemohon untuk ditunjukkan kepada petugas sewaktu-waktu jika diperlukan karena dokumen perizinan berfungsi sebagai jaminan kepastian hukum sehingga reklame yang di didirikan oleh si pemohon tidak di copot oleh satpol PP secara paksa sebelum masa waktu berlakunya telah habis."

\section{Tanggung Jawab}

Untuk mengetahui siapakah petugas/unit kerja pelayanan yang bertanggung jawab dalam penyelesaian keluhan/persoalan dalam pelaksanaan pelayanan, maupun yang bertanggung jawab memberikan rekomendasi apakah izin yang dimohon dapat disetujui atau tidak maka peneliti melakukan wawancara kepada Bapak Teuku Armia, SH dengan pertanyaan:

- Sejuh ini apakah ada masyarakat yang mengajukan keluhan/komplain dalam mengurus izin mendirikan reklame?

"Memang ada masyarakat yang mengeluh,misalnya tentang pengurusan izin mendirikan reklame yang memakan waktu lebih dari 5 hari. Namun biasanya lamanya pengurusan izin mendirikan reklame tersebut diakibatkan oleh kurangnya pengetahuan dari masyarakat tentang persyaratan pengurusan izin mendirikan reklame, dan karena banyaknya masyarakat yang mengurus izin apalagi kita tidak hanya menerbitkan izin bagi mendirikan reklame saja tetapi juga izin-izin lain sehingga para pemohon harus bersabar karena jika memang sesuai dengan waktunya maka izin tersebut pasti akan diterbitkan."

- Siapa pihak/unit kerja yang bertanggung jawab jika ada pemohon Izin Pemasangan Reklame yang mengajukan komplain/keluhan dan bagaimana penyelesaian terhadap komplain/keluhan tersebut?

"Petugas/unit kerja yang secara khusus bertanggung jawab itu tidak ada, si pemohon cukup datang ke instansi terkait (Dinas Pekerjaan Umum ataupun Kantor KPPT pada 
bagian kasi pengaduan).

- Bagaimana penyelesaian terhadap keluhan/komplain tesebut?

"Misalnya jika ada si pemohon yang mengeluh penyelesaian pengurusan izin reklame terlalu lama, kita cari tahu apa penyebabnya. Kita mencari solusi yang terbaik dan memberikan saran-saran maupun petunjuk kepada si pemohon agar mendapatkan informasi mengenai prosedur/tata cara maupun persyaratan dalam pengurusan mendirikan izin reklame."

- Sumber media/informasi apa yang bisa dicapai masyarakat untuk mengetahui bagaimana proses pengurusan Izin Pemasangan Reklame?

"Sumber informasi yang bisa digunakan oleh masyarakat dapat melalui website kppt.acehbaratkab.go.id/, sambungan telepon maupun fax atau mendatangi kantor KPPT ke bagian informasi dan pendaftaran.

- Apa tindakan yang dilakukan terhadap pemasangan reklame yang belum mendapat izin dan siapa saja pihak-pihak yang terkait dalam rangka penyelenggaraan tugas-tugas yang menyangkut dengan perizinan?

"Setiap pemasangan reklame harus terlebih dahulu mendapat izin tertulis dari pihak KPPT apabila ada pihak masyarakat yang mendirikan reklame tidak memiliki izin maka kami pihak KPPT akan menyurati pimpinan satpol PP agar mencopot secara paksa reklame yang tidak memiliki izin tersebut. Pihak yang terkait dalam penyelenggaraan izin tentunya pihak Dinas Pekerjaan Umum, pihak KPPT, DPKKD dan satpol PP yang bertugas mengawasi reklame yang tidak memiliki izin".

- Apakah ada kendala-kendala yang dihadapi oleh pihak KPPT dalam memberikan pelayanan pengurusan izin reklame maupun izin lainnya?

"Sejauh ini kendala yang dihadapi yaitu waktu penyelesaian pengurusan izin reklame kadangkala tidak selesai tepat waktu karena banyaknya masyarakat yang mengurus izin, tidak hanya izin reklame dan saja yang harus kita proses namun juga izin-izin lain seperti izin mendirikan usaha, IMB dan izin lainnya sehingga harus kita proses satu per satu dan kendala yang ada juga berasal dari masyarakat misalnya ada persyaratan yang kurang lengkap, sehingga memakan waktu lebih lama untuk menerbitkan izin mendirikan reklame. Oleh karena itu kita memandang perlu dilakukan pembinaan kepada masyarakat secara rutin namun hal ini belum dapat kita lakukan".

\section{e. Hasil Wawancara dengan Kabid Pendapatan Daerah (DPKKD)}

Kemudian sebagai informasi tambahan maka peneliti melakukan wawancara dengan Kabid Pendapatan Daerah (DPKKD) tentang Pembayaran Pajak dalam Pemasangan Reklame yaitu Bapak Muhdarsyah dengan pertanyaan:

- Bagaimana mekanisme pembayaran pajak pemasangan reklame apakah sudah telah diinformasikan secara jelas kepada masyarakat?

"Ya, pembayaran pajak pemasangan reklame sudah telah diinformasikan secara jelas kepada masyarakat atau si pemohon. Didalam pengurusan pajak reklame si pemohon akan mendapatkan arahan, penjelasan dan juga perkiraan biaya Pajak Reklame atau 
Billboardnya dari staf kami, kemudian si pemohon akan diberikan Tabel Nilai Jual Objek Pajak Reklame (NJOPR). Dalam Tabel NJOPR inilah maka si pemohon mengetahui semua gambaran skala penilaian jenis reklame, NSPR dalam ukuran/hari dan lokasi penempatan reklamenya.

- Apakah selama ini pihak DPKKD memberikan informasi kepada masyarakat tentang alur pelayanan pembayaran pajak dalam mendirikan papan reklame?

"Ya, sebagai lembaga pelayanan masyarakat yang setiap hari berhungan dengan masyarakat tentu harusnya banyak menyediakan informasi tentang pelayanan kedapa masyarakat terutama tentang alur pelayanan pembayaran pajak dalam mendirikan reklame. Informasi tersebut kami sampaikan melalui selembaran yang kami bagikan keseluruh masyarakat dan poster yang kami tempelkan di dinding ruang pelayanan, selain itu masyarakat juga dapat mengakses website kami dpkkd.acehbaratkab.go.id, guna mendapatkan informasi tentang bagaimana mekanisme alur pembayaran pajak mendirikan reklame.

- Kapan biaya/tarif pengurusan pajak pemasangan reklame dibayarkan oleh si pemohon?

"Pembayaran retribusi dilakukan selambat-lambatnya 15 hari kerja setelah surat pemberitahuan diterima oleh si pemohonatau sebelum pemasangan reklame".

- Apakah tarif pembayaran pajak reklame telah sesuai dengan peraturan perundangundangan yang berlaku?

"Ya tentu saja karena dasar atau petunjuk dalam menentukan tarif/biaya pengurusan pajak reklame tersebut berdasarkan Peraturan Bupati Aceh Barat No. 81 Tahun 2014 tentang Tata Cara Pelaksanaan Pajak Reklame".

- Siapakah unit kerja yang bertanggung jawab menerima biaya/tarif pajak reklame dalam pengurusan izin mendirikan reklame reklame?

"Yang bertanggung jawab menerima biaya/tarif pajak dalam pengurusan Izin reklame tersebut yaitu unit pengelola keuangan DPKKD".

- Apakah setiap pungutan tarif pajak reklame yang ditarik ditandai dengan tanda bukti resmi sesuai dengan jumlah yang dibayarkan?

"Ya, tentu saja setiap pungutan yang ditarik ditandai dengan tanda bukti resmi sebagai bukti dalam pengurusan izin mendirikan reklame tersebut dan dapat digunakan oleh si pemohon untuk ditunjukkan kepada petugas sewaktu-waktu jika diperlukan."

- Apa sanksi dari pihak Dinas Pengelolaan Keuangan dan Kekayaan Daerah apabila ada masyarakat yang tidak membayar pajak dari pemasangan Reklame?

"Jika dalam waktu 30 hari itu tidak juga dilunasi maka akan dikenakan sanksi administratif berupa denda sebesar 2 persen dari pajak yang akan dibayarkan oleh si pemohon dalam pemasangan reklame".

- Sumber media/informasi apa yang bisa dicapai masyarakat untuk mengetahui bagaimana proses pembayaran pajak pemasangan reklame? 
"Sumber informasi yang bisa digunakan oleh masyarakat dapat melalui website kami dpkkd.acehbaratkab.go.id sambungan telepon atau mendatangi kantor DPPKD ke bagian kasi pajak daerah.

\section{f. Hasil Wawancara Dengan Satpol PP}

Kemudian sebagai informan tambahan peneliti juga melakukan wawancara kepada Danru Satpol PP Bapak Is. Fahanyang bertugas mengendalikan reklame yang tidak mempunyai izin ataupun yang sudah jatuh tempo pemasangannya dengan pertanyaan sebagai berikut:

- Apa peran satpol pp dalam dalam mekanisme perizinan mendirikan papan reklame?

"Peran kami hanyalah menertibkan reklame yang tidak mempunyai izin atau reklame liar yang terpasang di sepanjang jalan, itupun harus ada surat perintah terlebih dahulu dari pihak kppt baru kami bertindak untuk mencopot papan reklame tersebut."

- Bagaimana pihak satpol pp dalam mengendalikan papan reklame yang tidak mempuyai izin yang terpasang sepanjang jalan?

"Seperti yang kami katakan tadi kami harus mendapatkan surat perintah terlebih dahulu dari pihak kppt baru kami melakukan survei ke lapangan dan mencopot reklame yang tidak mempunyai izin untuk diamankan ke kantor sebagai barang bukti, apabila pemiliknya datang untuk mengambil papan reklame tersebut mereka harus menunjukan bukti fisik yang resmi dalam izin mendirikan reklame."

- Apa sanksi yang diberikan bagi pemilik papan reklame yang tidak mempunyai izin?

"Kalau sanksi bagi pelanggar tidak ada, namun mereka harus melengkapi dokumendokumen resmi serta persyaratan administrasi dalam mendirikan papan reklame seperti pembayaran pajak dalam mendirikan papan reklame serta dokumen-dokumen izin yang di keluarkan dari pihak kppt.”

\section{g. Hasil Wawancara Dengan Masyarakat}

Kemudian sebagai informan tambahan peneliti juga melakukan wawancara kepada masyarakat yang telah mengurus izin mendirikan reklame sebanyak empat orang dengan pertanyaan serta hasil wawancaranya sebagai berikut:

- Apakah anda telah memahami bagaimana prosedur pengurusan izin dalam mendirikan papan reklame?

"Ya, ketika hendak mengurus perizinan mendirikan reklame saya cukup memahami bagaimana prosedurnya karena pihak KPPT sendiri telah menjelaskan kepada saya tata cara dalam pengurusanperizinan mendirikan reklameapalagi tidak hanya sekali ini saja saya mengurus izin, sebelumnya saya juga pernah mengurus izin untuk mendirikan reklame (Wawancara Ibrahim, hari Rabu, 03 Januari 2017, pukul 08.40 WIB di KPPT).”

Hal senada juga disampaikan oleh informan lainnya melalui petikan wawancara berikut:

"Sebelum saya datang ke kantor kppt saya memang tidak tahu bagaimana prosedur dalam mengurus mendirikan reklame. Setelah saya datang kesana dan mendengar penjelasan 
dari petugas yang bersangkutan baru saya paham.(Wawancara Azhar, hari Rabu, 03 Januari 2017, pukul 09.00 WIB di KPPT).”

Pendapat serupa juga disampaikan oleh informan lainnya yang selama ini menerima pelayaan dari kantor kppt berikut hasil kutipan wawancaranya:

"Mula-mula saya tidak paham bagaimana cara mengurus izin mendirikan reklame. Jadi ketika saya ingin mengurus izin maka barulah petugas bersangkutan menjelaskan bagaimana prosedur dalam mengurus izin mendirikan reklame (Wawancara Adi, hari Rabu, 03 Januari 2017, pukul 09.00 WIB di KPPT).”

Sama halnya dengan pendapat informan lainnya berikut hasil kutipan wawancaranya:

"Mulanya saya memang tidak mengerti bagaimana prosedur dalam mengurus izin mendirikan reklame sebelum diberitahukan oleh petugas setempat. Setelah diberitahukan barulah saya mengerti. Sebelumnya saya tidak tahu sama sekali (Wawancara Budi Ramadhan, hari Rabu, 03 Januari 2017, pukul 09.00 WIB di KPPT).”

\section{PENUTUP}

Bedasarkan hasil penelitian, Mekanisme Izin Pemasangan Reklame Di Kantor Pelayanan Perizinan Terpadu Kabupaaten Aceh Barat dapat di simpulkan sebagai berikut:

\section{a. Prosedur pelayanan pada KPPT.}

Prosedur Pelayanan KPPT bila dilihat dari segi kesedarhanaan, sudah dapat dikatakan efektif, karena prosuder pelayanan tidak berbelit-belit sesuai dengan tujuan pelayanan terpadu satu pintu. Si pemohon cukup melengkapi formulir permohonan izin mendirikan reklame dengan melengkapi persyaratan yang ada kemudian selebihnya akan diproses oleh pihak KPPT. Selain dilihat dari segi kesederhanaan, prosedur pelayanan juga di lihat dari segi kejelasan dan kepastian persyaratan maupun rincian biaya retribusi (Pajak), kepastian hukum, tanggung jawab, kelengkapan sarana dan prasarana serta kemudahan akses. Namun bila dilihat dari segi waktu belum dapat dikatakan efektif karena penyelesaian izin mendirikan reklame tersebut memakan waktu lebih dari 6 hari kerja atau tidak sesuai dengan waktu yang talah ditetapkan berdasarkan peraturan perundang-undangan. Dengan adanya penyederhanaan prosedur maka akan mewujudkan suatu sistem pelayanan yang praktis dan cepat sehingga kualitas pelayanan akan meningkat dan masyarakat puas dengan pelayanan yang didapatkan.

\section{b. Kendala-Kendala yang dihadapi oleh pihak KPPT}

Kendala- kendala yang dihadapi oleh pihak KPPT antara lain akibat banyaknya masyarakat yang mengurus izin mendirikan reklame mengakibatkan penyelesaian izin mendirikan reklame tidak dapat selesai sesuai dengan waktu yang telah ditentukan. Kendala yang juga dihadapi oleh pihak KPPT yaitu apabila masyarakat yang hendak mengurus izin tidak melengkapi persyaratan yang diminta sehingga proses penerbitan izin mendikan reklame menjadi terhambat dalam pemasangan reklame.

\section{c. Strategi Pengawasan KPPT.}

Strategi Pengawasan terhadap penyelenggaraan reklame yaitu dengan menindak lanjuti reklame yang tidak mempunyai izin atau reklame liar yang terpasang di sepanjang jalan untuk di copot dan diamankan kekantor sebagai barang bukti, apabila pemiliknya datang untuk mengambil papan reklame tersebut mereka harus menunjukan bukti fisik yang resmi dalam izin mendirikan reklame. 


\section{DAFTAR PUSTAKA}

Adrian Sutedi, 2010. Hukum Perizinan Dalam Sektor Pelayanan Publik, Sinar Grafika, Jakarta.

Bagong, Suyanto dan Sutinah. 2008. Metode Penelitian Sosial: Berbagai Alternatif Pendekatan. Jakarta: Kencana Prenada Media Group.

Bungin, M. Burhan. 2008. Penelitian Kualitatif. Jakarta: Kencana Prenada Media Group.

Denzin K. Norman dan Lincoln S. Yvonna. 2009. Hand Book Of Qualitative Research. New Delhi: Sage Publications.

Dounloud, Minggu 22 Oktober 2017 http://www.perizinan.info/fom_index.php .com/29-122009/20.33 WIB.

Goenawan, Kian. 2008. Izin Beres Bisnis Sukses. Yogyakarta: Pustaka Grahatama.

Khayatudin, 2012, Pengantar Mengenal Hukum Perizinan, Uniska Press, Kediri.

Mardalis. 2003. Metode Penelitian Suatu Pendekatan Profosal. Jakarta : PT. Bumi Aksara.

Masli Ali, 2005, Reka Reklame, Galangpress, Jakarta.

Napitupulu, Paimin.2006. Pelayanan Publik dan Customer Statisfiction. Bandung: Alumni.

Nasution. 2003. Metode Research, Jakarta : PT. Bumi Aksara.

Rusmanto Gunawan, 2010.Promosi Melalui Media Iklan Televisi dan Efektivitasnya, Rajawali Press.

Soehartono,2008. Metode Penelitian Deskriptif. Yogyakarta: Mandiri Prima.

Sri. Pudyatmoko, Y. 2009. Perizinan Problem dan Upaya Pembenahan, Jakarta : PT. Gramedia Widiasarana Indonesia.

Sudrajat, 2005, Dasar-Dasar Penelitian Ilmiah, Bandung: Pustaka Setia.

Sugiyono. 2013. Metode Penelitian Kuantitatif Kualitatif dan R \& D. Bandung : Alfabeta.

Sukandarrumidi. 2002 .Metode Penelitian untuk Pemula .Universitas Gadjah Mada.Yogyakarta

\section{Peraturan dan Undang-undang}

Peraturan Pemerintah Nomor 41 Tahun 2007 Tentang Pelayanan Perizinian

Peraturan Mendagri Nomor 20 Tahun 2008 Tentang Implementasi Pajak Reklame.

Peraturan Bupati Aceh Barat Nomor 81 Tahun 2014, Tentang Pelaksanaan Pajak Reklame.

Peraturan Bupati Aceh Barat Nomor 12 Tahun 2007 Tentang Susunan Organisasi dan Tata Kerja Kantor Perizinan Terpadu Satu Pintu. 
Qanun Kabupaten Aceh Barat Nomor 4 Tahun 2008 Tentang Susunan Organisasi dan Tata Kerja Lembaga Teknis Daerah Kabupaten Aceh Barat .

Qanun Kabupaten Aceh Barat No. 4 Tahun 2013 Tentang Perubahan Atas Qanun Kabupaten. Aceh Barat No. 11 Tahun 2012 tentang Susunan Organisasi dan Tata Kerja Lembaga Teknis Daerah Kabupaten Aceh Barat. 